\title{
Who Believes Hoaxes? Xenophobia and Religiosity as Hoax Predictors among Social Media Users
}

\section{Morissan, Andy Corry Wardhani, Tri Dhiah Cahyowati}

To Link this Article: http://dx.doi.org/10.6007/IJARBSS/v11-i2/8383

DOI:10.6007/IJARBSS/v11-i2/8383

Received: 13 December 2020, Revised: 10 January 2021, Accepted: 19 January 2021

Published Online: 04 February 2021

In-Text Citation: (Morissan et al., 2021)

To Cite this Article: Morissan, Wardhani, A., C., \& Cahyowati, T. D. (2021). Who Believes Hoaxes? Xenophobia and Religiosity as Hoax Predictors among Social Media Users. International Journal of Academic Research in Business and Social Sciences, 11(2), 1-21.

Copyright: (c) 2021 The Author(s)

Published by Human Resource Management Academic Research Society (www.hrmars.com)

This article is published under the Creative Commons Attribution (CC BY 4.0) license. Anyone may reproduce, distribute, translate and create derivative works of this article (for both commercial and non-commercial purposes), subject to full attribution to the original publication and authors. The full terms of this license may be seen at: http://creativecommons.org/licences/by/4.0/legalcode

Vol. 11, No. 2, 2021, Pg. 1 - 21

Full Terms \& Conditions of access and use can be found at http://hrmars.com/index.php/pages/detail/publication-ethics 


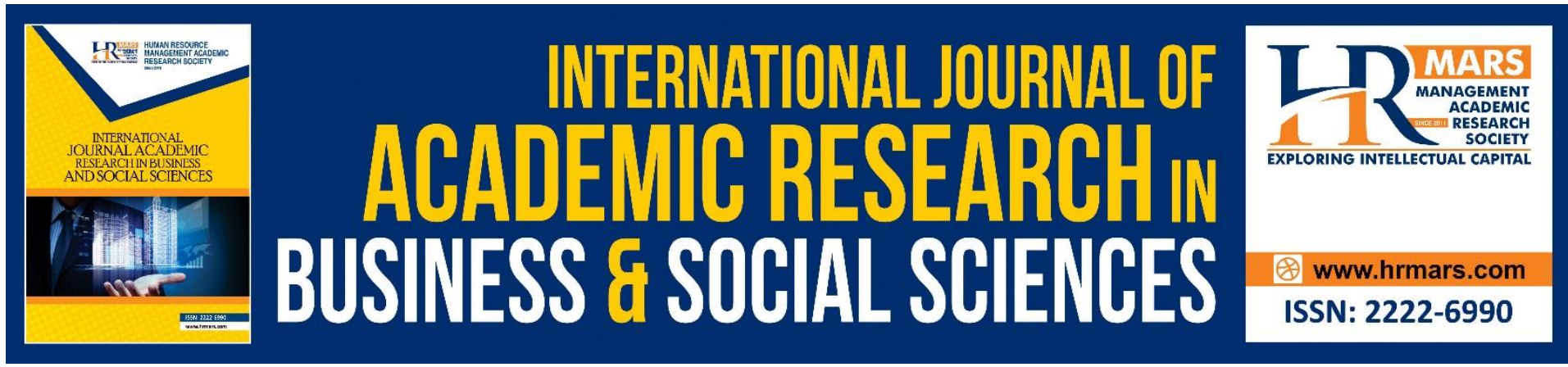

\title{
Who Believes Hoaxes? Xenophobia and Religiosity as Hoax Predictors among Social Media Users
}

\author{
Morissan \\ Fakultas IImu Komunikasi, Universitas Mercu Buana, Jakarta, Indonesia \\ Email: morissan@mercubuana.ac.id \\ Andy Corry Wardhani \\ Program Studi Magister Ilmu Komunikasi, Universitas Lampung, Indonesia \\ Email: andy.corry@fisip.unila.ac.id \\ Tri Dhiah Cahyowati \\ Fakultas IImu Komunikasi, Universitas Mercu Buana, Jakarta, Indonesia \\ Email:Tri.diah@mercunuana.ac.id
}

\begin{abstract}
Several studies show that social media is a source of hoaxes. This study aims to find out who among Muslim social media users who easily believe hoaxes. The dependent variable in this study was the ease of believing hoaxes, while religiosity and xenophobia are predictor variables. Demographic attributes such as education, income, age, and time spent using social media are control variables. This study uses a sample survey with a structured questionnaire. The purposive sampling technique used resulted in 350 respondents residing in Jakarta and surrounding areas. Data analysis was performed using hierarchical multiple regression and structural equation modeling (SEM). Findings show that xenophobia gives an exceptionally large influence of 71.8 percent in encouraging people to easily believe hoaxes while religiosity contributes $13.5 \%$. The combined strength of the two constructs even reaches more than $85 \%$ to further drive Muslims to believe hoaxes. The resulting regression equation also shows that xenophobia tends to increase with the religiosity rise. Analysis using structural equation modeling also supports the proposed structural model which involves the four constructs namely hoaxes, religiosity, xenophobia, and social media use.
\end{abstract}

Keywords: Xenophobia, Religiosity, Hoax, Social Media, Islam

\section{Introduction}

Identity politics in political campaigns still cannot be left behind in every general election in Indonesia. In recent elections, with the help of the Internet, Indonesia has experienced an escalation of identity politics in which various groups based on race, religion, ethnicity, social, or culture tend to promote their own interests without regard to the interests of larger 
political groups (Hui, 2018). Hoaxes with sectarian and racist narratives has been used to arouse ethnic and religious sentiments in political campaigns. Black campaign by spreading hoaxes on social media was first discovered in 2012 during the Jakarta governor election. At that time Joko Widodo, a Muslim, along with his running mate Basuki Tjahaja Purnama, a Christian Chinese descent, campaigned for Governor and Vice Governor of the capital Jakarta. Black campaigns milling about on social media accused Widodo of coming from the Christian family and communist supporters while Basuki was accused of being infidels. But despite black campaigns, both succeeded in winning the election.

The spread of hoaxes increased during the 2014 presidential election which pitted Joko Widodo against former Army general Prabowo Subianto. During the campaign, Jokowi was continually the target of hoaxes which accused him of being a child of a member of the defunct Indonesian Communist Party. The effect of hoax news and black campaigns reached a peak in 2017 when a wave of a demonstration by conservative Muslim groups succeeded in pressuring the court to bring down a Christian, Basuki Tjahaja Purnama, from his position as Governor of Jakarta on charges of blasphemy.

\section{Fake News}

Fake news is a form of hoax that happens in the press and the social networks (Torto, 2018): therefore, a fake news is a hoax but there are many forms of hoax that cannot be labeled "fake news" for example, an effort to fool people for the fun (Husted, 2018). Fake news can be defined as news articles that are intentionally made wrong and can be proven wrong and can mislead readers (Allcott \& Gentzkow, 2017). This definition includes all news articles that are deliberately engineered. Fake news can come from various websites. For example, some sites are built entirely to create misleading articles.

Fake news has trumped up attention across cultures from the United States Elections to the Arab Spring. Several studies have been conducted to find out why people can easily believe fake news and its impact on social relationships.

Several studies have been conducted after the 2016 US presidential election to investigate the effects of fake news on social media (Allcott \& Gentzkow, 2017) and the study produced several findings including 1) As many as 62 percents of adults in the US get news from the social media (Gottfried and Shearer, 2016); 2) The most popular fake news is more shared on Facebook than the most popular news articles from the mainstream media (Silverman, 2016); 3) Many people who read fake news state that they believe it (Silverman and Singer-Vine, 2016); and 4) The most often discussed fake news tends to support Donald Trump compared to Hillary Clinton (Silverman, 2016). Based on these facts, many are of the view that Donald Trump would not have been elected president if it had not been for the influence of fake news (Parkinson, 2016; Dewey, 2016).

Rampersad and Althiyabi (2019) investigate the influence of demographics and culture on the spread of fake news via social media in Saudi Arabia. Based on a quantitative study, it finds that culture has the most significant impact on the spread of fake news. Results shows that age and not gender or education has a greater influence on the acceptance of fake news in particular cultures.

A study of fake news and increased persecution in Indonesia by a Singaporean research institution found that the new media industry favouring sensational headlines, a highly unequal material-technological distribution, and the rapid expansion of formal education and associated unemployment among educated young people enhance the effectiveness of fake news (Azali, 2017). 
Talwar et al (2019) found that believing and sharing fake news among social media users in India were encouraged by the highlevel of online trust, self-disclosure, fear of being excluded from social or peer groups, and negative emotion resulting from continuous use of online social media. Duffy et al (2019) studied how fake news affects interpersonal relationships between sender and receiver. They ran 12 one-hour focus groups of 88 adult Singaporean in 2016 and 2017. They found that while sharing news can build relationships, fake news can undermine them.

The formation of accurate and strong beliefs will guide individual behavior, and one of the contributors to inaccurate beliefs is fake news that appears as if it comes from a legitimate source and is promoted on social media to deceive the public for ideological or financial gain (Lazer et al. , 2018). Because of the widespread dissemination of false information and news can give negative consequences for individuals and society, it is very important to investigate who might be the most vulnerable to fake news and why.

\section{Xenophobia}

In literature, a sense of fear of the presence of a foreign party is known as xenophobia. The word xenophobia comes from the Greek Xenos, which means 'stranger', and phobia which means, 'fear'. Xenophobia can be defined as "attitudinal, affective, and behavioral prejudice toward immigrants and those perceived as foreign" (Yakushko, 2009). This means that people who have xenophobia have attitudes, emotions, and behaviors based on a negative perspective on immigrants and those who are considered strangers (Yakushko, 2009). More specifically, Reynolds and Vine (1987) state that xenophobia is "a psychological state of hostility or fear of outsiders" (p. 28). Crowther (1995) also emphasizes that xenophobia focuses on individuals from "other countries" and to whom native individuals have "intense dislike or fear" (p. 1,385). On the other hand, according to Landis (as cited in Cashdan, 2001, p. 761) xenophobia consists of "negative attitudes, insults, distrust."

The meaning of xenophobia often overlaps with racism. Xenophobia implies behavior based on the idea that others are "foreign" to his or her group, and racism requires differences based on physical characteristics, such as skin color, hair type and facial features (Karlsson, 2010). Although much research has been done to study the concept of xenophobia with other phenomena, there is no consistency in the measurement of xenophobia (van der Veer, 2011). At the community level, xenophobia measurements are carried out through the number of officially reported inter-ethnic conflicts involving new immigrants (for example, Cashdan, 2001). In assessing xenophobic attitudes, researchers usually use questions about general attitudes towards immigration and immigrants (for example, Eses, Dovidio, Jackson, \& Armstrong, 2001).

\section{Religiosity}

Understanding of religion and religiosity as variables that have several dimensions is rooted in religious theories that emerged since the early 1900s and have been repeatedly revised, especially during the second half of the 1900s (Pearce et al., 2016). For example, Joachim Wach (1944) proposes a three-dimensional model including the "theoretical" dimension, which refers to the strength of doctrinal obedience, the "cult" dimension which is the level of one's worship practices, and the "sociological" dimension, or social involvement in community activities.

There is evidence that religious fundamentalists and dogmatic individuals lack analytical power (Bronstein, 2018). Dogmatic individuals exhibit weak analytic reasoning when they 
must carry out evaluating syllogism tasks (Martin, 2008). These individuals also produce fewer correct answers on the Cognitive Reflection Test (CRT; Frederick, 2005), which consists of question items with intuitive-but-wrong answers that must be mastered using analytical thinking to arrive at the correct answer (Friedman \& Jack, 2018). Religious fundamentalists also have less analytic thinking and are less active in open thinking. Religious beliefs are also associated with worse CRT performance (Bahc, ekapili \& Yilmaz, 2017; Shenhav, Rand, \& Greene, 2012; Pennycook, Cheyne, Barr, Koehler, \& Fugelsang, 2014).

Several studies show that delusion-prone individuals, those who support unusual ideas and are considered to be on a continum with psychosis, are very easy to believe fake news (see Rössler et al., 2015; Van Os, Hanssen, Bijl, \& Ravelli, 2000). Psychosis is a serious mental illness that affects one's personality and ability to know what's real (Cambridge dictionary). People with psychosis tend to quickly believe in stories about conspiracy theories (Dagnall, Drinkwater, Parker, Denovan, \& Parton, 2015), easily believe in paranormal phenomena (Pechey \& Halligan, 2011), and easily accept unreasonable explanations as something that makes sense (Bronstein \& Cannon, 2017; Zawadzki et al., 2012).

\section{Previous Research}

This study aims to answer the question of whether religiosity and xenophobia have a role in encouraging someone to believe more easily in fake news. Earlier study shows that individuals who support imaginary-like ideas (for example, think that people can communicate telepathically), dogmatic individuals, and religious fundamentalists, are more likely to believe fake news (Bronstein, M. V., et al., 2018).

Allcott and Gentzkow (2017) found three factors that tended to be significantly correlated with one's ability to distinguish between factual news and fake news: people who spend more time consuming the media, people with higher education, and older people. People with one of these factors have more accurate beliefs about the news. They also found a significant relationship between sex and the acceptance level of fake news (Allcott \& Gentzkow, 2017).

In this case, the relationship between education and the ability to determine factual news needs to be emphasized. Education can help to avoid misperceptions because of the ability to distinguish fact from fiction. Education equips people with better instruments to fight inappropriate information (Flynn et al., 2017). Another study investigates the relationship between the use of social media and political knowledge. Lee and Oh (2013) examined the relationship between the early Twitter user and their knowledge by using a South Korean respondent panel. They found a correlation between Twitter use and knowledge of factual public information.

In the same vein, Yoo and Gil de Zuniga (2014) found no direct relationship between the use of Facebook or Twitter on general or political knowledge, but they found a knowledge gap between Facebook users who came from different socioeconomic status ( Yoo \& Gil de Zúñiga, 2014).

\section{Research Questions and Hypothesis}

The few studies conducted in this field indicate a clear need to better understand the influence of xenophobia, religiosity, demographic factors, and the use of social media in encouraging an individual to easily believe hoaxes. Thus this study poses a question: Is there a significant relationship between xenophobia and religiosity with the ease of believing hoax after controlling for demographic predictors and social media use? 
This study aims to find out who among social media Muslim users vulnerable to believe hoaxes? The dependent variable in this study is the ease level of believing hoaxes. The xenophobia and religiosity variables will be tested as independent variables (predictors). Also, this study will measure whether controlling variables such as education, income, age, gender, and time spent using social media affect Muslims to be more prone to believe fake news. In the final section, this research wants to propose a structural model (Figure 1) that can be used to explain the relationships between variables. The proposed structural model is tested with structural equation modeling (SEM) analysis which allows testing of the relationship model between variables simultaneously by combining the power of factor analysis and path analysis (Saxena \& Khana, 2013).

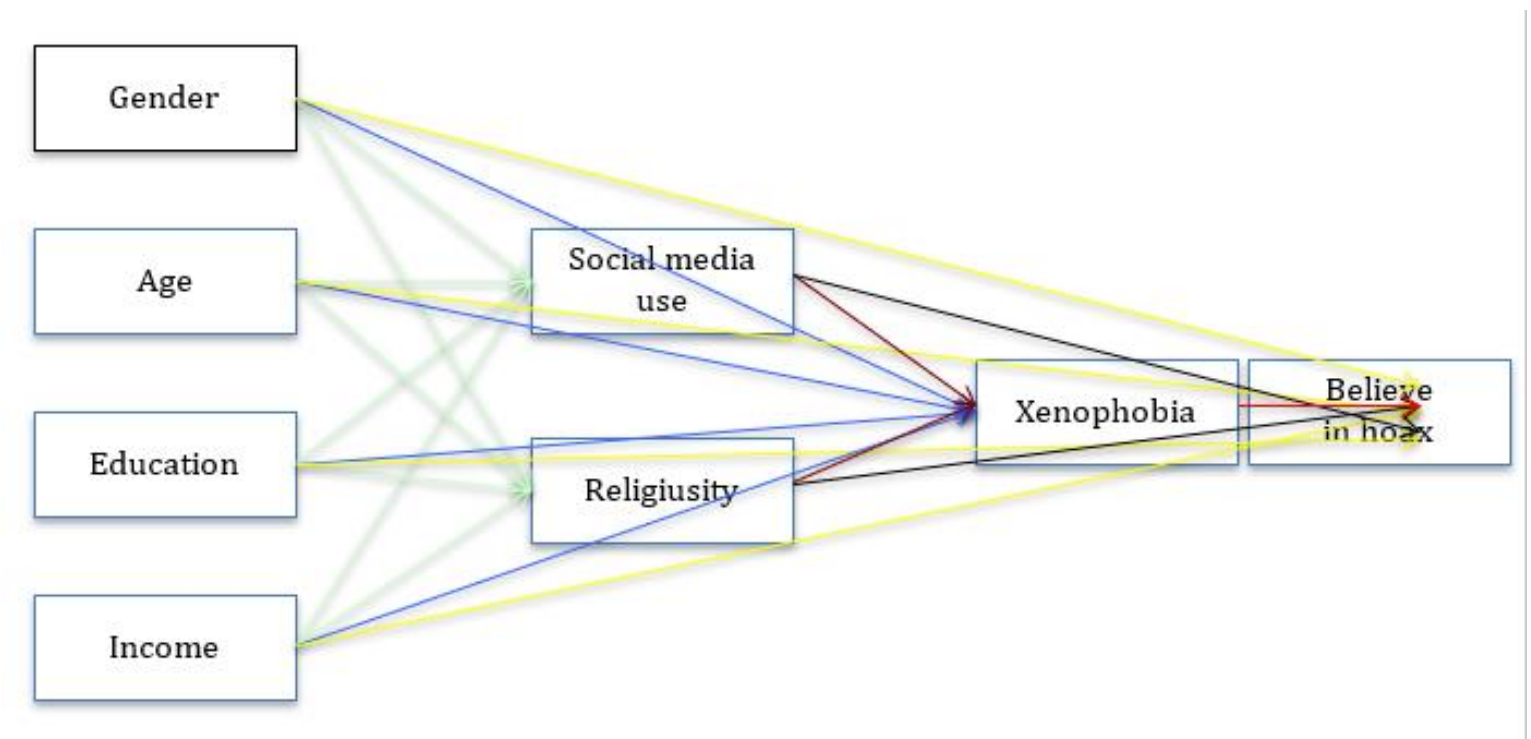

Figure 1: The proposed structural model

Based on the discussion above, it can be said there is a strong suspicion that xenophobia and religiosity have a role in encouraging people to easily believe in false news. Thus, the research problem formulation can be formulated as follows:

a) Do xenophobia and religiosity influence Muslims to believe hoaxes?

b) Do demographic attributes such as education, income, age, gender, and time spent using social media influence Muslims to believe hoaxes?

c) How do xenophobia and religiosity correlate with the ease of believing hoaxes after controlling for demographic factors?

\section{Research Hypothesis}

$\mathrm{H} 1$ : There is a significant relationship between xenophobia and the ease level to believe hoaxes.

$\mathrm{H} 2$ : There is a significant relationship between religiosity and the ease level to believe hoaxes

$\mathrm{H} 4$ : There is a significant relationship between time spent using social media and the ease level to believe hoaxes

$\mathrm{H} 5$ : There is a significant relationship between xenophobia and religiosity with the ease level to believe hoaxes after controlling demographic factors. 
Based on the above research question and hypothsis, the objectives of the study can be formulated as the following:

- To find out whether xenophobia and religiosity influence Muslims to believe hoaxes.

- To determine whether demographic attributes such as education, income, age, gender, and time spent using social media influence Muslims to believe hoaxes.

- To find out whether xenophobia and religiosity correlate with the ease of believing hoaxes after controlling for demographic factors.

\section{Methods}

This research was conducted in the Greater Jakarta area which includes the capital city of Jakarta and surrounding areas with a population of around 30 million people which is the most densely populated and fastest-growing region in Indonesia and one of the areas where most of the population has access to media. This study uses a sample survey with a structured questionnaire and the sampling technique used is purposive sampling with criteria: adult Muslim and active social media users. Questionnaires were distributed online which generated 350 respondents.

The xenophobia variable was measured using a 5-point Likert scale ( 1 = strongly disagree and 5 = strongly agree) by placing 16 statement items adapted from van der Veer (2011) in the questionnaire including: "Number of China immigrant in Indonesia is uncontrollable"; "Foreigners from China take jobs from Indonesians"; "Interacting with strangers makes me nervous". The measurement of xenophobia resulted in the lowest score of 16 which means the level of xenophobia is exceptionally low and the highest 80 which means the level of xenophobia is extremely high.

Religiosity measurement does not cover all dimensions as discussed in the literature review because not all of them are relevant but only on behaviors that can be directly observed, both at the private or public level. Religiosity variables are measured using a 5point Likert scale ( 5 = strongly agree and $1=$ strongly disagree) by submitting nine items of statements including: "I always pray five times a day"; "I always pray in the mosque"; "Women must wear the hijab".

The dependent variable in this study is the respondents' ease level to believe hoaxes. As many as 21 hoaxes that once circulated on social media were used in the questionnaire and respondents were asked to assess whether the statements was 'true', 'false' or 'do not know', including: "President Jokowi's family was Christian"; "Indonesia's economy is controlled by 'nine dragons' from China"; "Communist party revives in Indonesia"; "President Jokowi is a supporter of communist party".

\section{Data Analysis}

The first part of the analysis was conducted using SPSS through the following steps. First, the independent sample t-test and ANOVA were used to test differences in the ease level to believe hoaxes among three predictors namely (1) gender: male and female (2) level of education and (3) income. Second, the Pearson correlation was carried out to examine the relationship between the following variables: (1) xenophobia, (2) religiosity, and (3) the use of social media. Third, multiple hierarchical regression is conducted to answer the question: Is there a significant influence of the two main predictors, xenophobia and religiosity, on the respondents' ease level to believe hoaxes by controlling other known predictors?

Multiple hierarchical regression is carried out in four blocks as follows. Demographic factors are assessed in the first block. The second block includes the social media usage 
variable. The third block includes the religiosity variable. In the last block, xenophobia variable is added to the model to test whether xenophobia can function as a predictor for Muslims to easily believe hoaxes by controlling religiosity and other independent variables.

Ease to believe hoax = sex, age, education, and income (Block 1 )

+ Use of social media (Block 2)

+ Religiosity (Block 3)

+ Xenophobia (Block 4)

In the final part, this research wants to propose a structural model that can explain the relationship between variables involved in this study, namely the use of social media, religiosity, xenophobia, and hoax by using a structural equation modeling (SEM) approach that combines the power of factor analysis and path analysis. According to Singh (2009), SEM is a more advanced technique than other multivariate techniques because it can predict a series of interdependent interrelated relationships simultaneously.

According to Byrne (1998), SEM has an advantage because this technique takes into account measurement errors during the model testing process and can combine observed variables (indicators) and latent variables simultaneously during model testing. In this study, SEM analysis was carried out in two main steps; first, testing the measurement model and second, testing the structural model. The measurement model provides a series of relationships that show how the observed variables represent latent variables and are tested using confirmatory factor analysis (CFA). The structural model examines the conceptual representation of the relationship between latent variables to find out whether the relationship and also the proposed structural model meets the minimum specified conditions or not.

\section{Research Results}

As shown in Table 1, the distribution of the questionnaire produced a sample of 314 respondents consisting of 132 women (42\%) and 182 men (58\%). The average age of the respondents was 27.74 years $(S D=10.32$ ) with the youngest respondent being 15 years old and the oldest 58 years. The education level of most respondents was a bachelor's degree (38.2\%) with an average income of less than Rp. 6 million / month (67\%). In terms of social media usage, this study only focuses on the duration, ie the time spent by respondents using social media consisting of 11 levels, ranging from less than one hour/day (weight 1) to more than 20 hours/day (weight 11). The results of data collection showed that respondents used social media at all levels, from the lightest to the heaviest. However, the use of social media mostly is 2 to 5 hours per day (52.5\%).

Before the statistical analysis is conducted, this study needs to examine several assumptions as a condition before employing a regression analysis that includes sample size, data normality, linearity, homoscedasticity, and the absence of multicollinearity. The multicollinearity test between the independent variables does not show a correlation with a coefficient value higher than 0.7 which is used as a general standard of multicollinearity assumptions; thus, the multicollinearity assumptions are met. In this case, the correlation between the predictor variables is in the distance between the minimum $r=-0.24$ to the maximum $r=+0.38$. The assumption of a linear relationship between the independent and dependent variables as a condition of regression analysis in this research model is also fulfilled when looking at the normal PP plot graphic where all values representing the relationship 
between all $X$ and $Y$ variables are very close around the best-fit line, thus the assumption of homoscedasticity is fulfilled. Furthermore, testing to check outliers is conducted by examining scatterplot charts that do not show any value that exceeds the standard deviation of $-3 \sigma$ or + $3 \sigma$. The residual standard value is in the range of -2.70 to +2.16 . Similarly, the value for Cook's distance is between 0.00 to 0.064 which does not exceed 1.00. Thus, there are no outliers in the research data as a condition for multiple regression analysis. To fulfill the assumption of normal distribution in sampling, the bootstrapping technique is used by sampling 2000 times (resampling) with SPSS version 25 which is also used for all analyzes in this study.

Table 1. Descriptive Statistics

\begin{tabular}{|c|c|c|c|c|c|}
\hline Demography & Frequency & $\%$ & Demography & Frequency & $\%$ \\
\hline Gender & & & Monthly income & & \\
\hline Male & 182 & 58 & Below Rp 2 M & 70 & 22,3 \\
\hline Female & 132 & 42 & $\mathrm{Rp} 2-5,9 \mathrm{M}$ & 140 & 44,6 \\
\hline Age & & & $\mathrm{Rp} 6-9,9 \mathrm{M}$ & 50 & 16 \\
\hline $15-24$ & 175 & 55,7 & Rp $10-13,9 \mathrm{M}$ & 22 & 7 \\
\hline $25-34$ & 68 & 21,7 & Rp $14-17,9 \mathrm{M}$ & 10 & 3,2 \\
\hline $35-44$ & 39 & 12,4 & Rp $18-19,9 \mathrm{M}$ & 6 & 1,9 \\
\hline $45-54$ & 27 & 8,6 & Above $\operatorname{Rp} 20 \mathrm{M}$ & 16 & 5,1 \\
\hline Above 55 & 5 & 1,6 & Social media use & & \\
\hline Education & & & Below 1 hour & 14 & 4,5 \\
\hline Student & 86 & 27,4 & $2-5$ hours & 164 & 52,2 \\
\hline Bachelor & 120 & 38,2 & $6-9$ hours & 68 & 21,6 \\
\hline Master & 56 & 17,8 & $10-13$ hours & 36 & 11,5 \\
\hline \multirow[t]{3}{*}{ PhD } & 52 & 16,6 & $14-17$ hours & 22 & 7,0 \\
\hline & & & $18-20$ hours & 6 & 1,9 \\
\hline & & & Above 20 hours & 4 & 1,3 \\
\hline
\end{tabular}

Rp $1 \mathrm{M}=$ US\$ 64.3

\section{Demographic Influence}

The first stage of data analysis was conducted to determine whether the four demographic factors (gender, age, education, and income) which are independent variables can be used to predict the other four variables in this study, namely the use of social media, religiosity, xenophobia, and respondents' ease level to believe hoax which at this stage are all considered as dependent variables. Calculations employing multiple regression analyses are performed to determine the effect of the four demographic factors. 
Table 2: Correlation coefficient between variables

\begin{tabular}{|c|c|c|c|c|c|c|c|c|c|}
\hline & & 1 & 2 & 3 & 4 & 5 & 6 & 7 & 8 \\
\hline \multirow{4}{*}{ 1. Gender } & Pearson & 1 & & & & & & & \\
\hline & Correlation & & & & & & & & \\
\hline & $\begin{array}{l}\text { Sig. (2- } \\
\text { tailed) }\end{array}$ & & & & & & & & \\
\hline & $\mathrm{N}$ & 314 & & & & & & & \\
\hline \multirow{4}{*}{ 2. Age } & Pearson & 0,004 & 1 & & & & & & \\
\hline & Correlation & & & & & & & & \\
\hline & $\begin{array}{l}\text { Sig. (2- } \\
\text { tailed) }\end{array}$ & 0,950 & & & & & & & \\
\hline & $\mathrm{N}$ & 314 & 314 & & & & & & \\
\hline \multirow{3}{*}{ 3. Education } & Pearson & 0,045 & 0,105 & 1 & & & & & \\
\hline & Correlation & & & & & & & & \\
\hline & $\begin{array}{l}\text { Sig. }(2- \\
\text { tailed) }\end{array}$ & 0,431 & 0,064 & & & & & & \\
\hline \multirow{5}{*}{ 4. Income } & $\mathrm{N}$ & 314 & 314 & 314 & & & & & \\
\hline & Pearson & $.129^{*}$ & 0,066 & $.134^{*}$ & 1 & & & & \\
\hline & Correlation & & & & & & & & \\
\hline & $\begin{array}{l}\text { Sig. (2- } \\
\text { tailed) }\end{array}$ & 0,022 & 0,245 & 0,017 & & & & & \\
\hline & $\mathrm{N}$ & 314 & 314 & 314 & 314 & & & & \\
\hline \multirow[t]{3}{*}{$\begin{array}{l}\text { 5. Social } \\
\text { media use }\end{array}$} & $\begin{array}{l}\text { Pearson } \\
\text { Correlation }\end{array}$ & $-0,089$ & $-.175^{* *}$ & $\begin{array}{c}- \\
.176^{* *}\end{array}$ & $-.244^{* *}$ & 1 & & & \\
\hline & $\begin{array}{l}\text { Sig. (2- } \\
\text { tailed) }\end{array}$ & 0,116 & 0,002 & 0,002 & 0,000 & & & & \\
\hline & $\mathrm{N}$ & 314 & 314 & 314 & 314 & 314 & & & \\
\hline \multirow{4}{*}{ 6. Religiosity } & Pearson & 0,019 & 0,025 & $.232^{* *}$ & $.127^{*}$ & - & 1 & & \\
\hline & Correlation & & & & & $.181^{* *}$ & & & \\
\hline & $\begin{array}{l}\text { Sig. }(2- \\
\text { tailed) }\end{array}$ & 0,739 & 0,665 & 0,000 & 0,024 & 0,001 & & & \\
\hline & $\mathrm{N}$ & 314 & 314 & 314 & 314 & 314 & 314 & & \\
\hline \multirow{3}{*}{ 7.Xenophobia } & Pearson & $-0,102$ & 0,034 & $.125^{*}$ & $-0,038$ & 0,005 & $.349^{* *}$ & 1 & \\
\hline & Correlation & & & & & & & & \\
\hline & $\begin{array}{l}\text { Sig. }(2- \\
\text { tailed) }\end{array}$ & 0,071 & 0,548 & 0,027 & 0,507 & 0,932 & 0,000 & & \\
\hline \multirow{5}{*}{ 8. Hoax } & $\mathrm{N}$ & 314 & 314 & 314 & 314 & 314 & 314 & 314 & \\
\hline & Pearson & $-.130^{*}$ & 0,057 & 0,057 & $-0,026$ & - & $.378^{* *}$ & $.763^{* *}$ & 1 \\
\hline & Correlation & & & & & 0,072 & & & \\
\hline & $\begin{array}{l}\text { Sig. (2- } \\
\text { tailed) }\end{array}$ & 0,021 & 0,316 & 0,318 & 0,643 & 0,201 & 0,000 & 0,000 & \\
\hline & $\mathrm{N}$ & 314 & 314 & 314 & 314 & 314 & 314 & 314 & 314 \\
\hline
\end{tabular}

*. Correlation is significant at the 0.05 level (2-tailed).

**. Correlation is significant at the 0.01 level (2-tailed). 
Table 3: Hierarchical multiple regression

\begin{tabular}{|c|c|c|c|c|c|c|}
\hline \multirow{2}{*}{\multicolumn{2}{|c|}{ Model }} & \multicolumn{2}{|c|}{$\begin{array}{l}\text { Unstandardized } \\
\text { Coefficients }\end{array}$} & \multirow{3}{*}{$\begin{array}{c}\text { Standardized } \\
\text { Coefficients } \\
\text { Beta } \\
\end{array}$} & \multirow{3}{*}{$\frac{\mathbf{t}}{3,134}$} & \multirow{3}{*}{$\frac{\text { Sig. }}{0,002}$} \\
\hline & & \multirow{2}{*}{$\frac{B}{5,926}$} & \multirow{2}{*}{$\begin{array}{l}\begin{array}{l}\text { Std. } \\
\text { Error }\end{array} \\
1,891\end{array}$} & & & \\
\hline 1 & (Constant) & & & & & \\
\hline & Gender & $-1,538$ & 0,671 & $-0,130$ & $-2,292$ & 0,023 \\
\hline & Age & 0,031 & 0,033 & 0,052 & 0,925 & 0,356 \\
\hline & Education & 0,339 & 0,324 & 0,060 & 1,046 & 0,296 \\
\hline & Income & $-0,046$ & 0,126 & $-0,021$ & $-0,365$ & 0,716 \\
\hline \multirow[t]{6}{*}{2} & (Constant) & 7,345 & 2,180 & & 3,370 & 0,001 \\
\hline & Gender & $-1,589$ & 0,672 & $-0,134$ & $-2,366$ & 0,019 \\
\hline & Age & 0,024 & 0,033 & 0,041 & 0,715 & 0,475 \\
\hline & Education & 0,282 & 0,326 & 0,050 & 0,863 & 0,389 \\
\hline & Income & $-0,082$ & 0,129 & $-0,037$ & $-0,634$ & 0,527 \\
\hline & Social media & $-0,195$ & 0,149 & $-0,077$ & $-1,304$ & 0,193 \\
\hline \multirow[t]{7}{*}{3} & (Constant) & $-1,729$ & 2,383 & & $-0,726$ & 0,469 \\
\hline & Gender & $-1,538$ & 0,623 & $-0,130$ & $-2,471$ & 0,014 \\
\hline & Age & 0,030 & 0,031 & 0,051 & 0,953 & 0,341 \\
\hline & Education & $-0,166$ & 0,309 & $-0,029$ & $-0,538$ & 0,591 \\
\hline & Income & $-0,143$ & 0,120 & $-0,065$ & $-1,189$ & 0,235 \\
\hline & Social media & $-0,064$ & 0,140 & $-0,025$ & $-0,456$ & 0,648 \\
\hline & Religiosity & 0,384 & 0,053 & 0,390 & 7,182 & 0,000 \\
\hline \multirow[t]{8}{*}{4} & (Constant) & $-8,034$ & 1,671 & & $-4,809$ & 0,000 \\
\hline & Gender & $-0,709$ & 0,430 & $-0,060$ & $-1,649$ & 0,100 \\
\hline & Age & 0,015 & 0,021 & 0,026 & 0,714 & 0,476 \\
\hline & Education & $-0,423$ & 0,212 & $-0,075$ & $-1,992$ & 0,047 \\
\hline & Income & $-0,038$ & 0,083 & $-0,017$ & $-0,465$ & 0,642 \\
\hline & Social media & $-0,175$ & 0,096 & $-0,069$ & $-1,820$ & 0,070 \\
\hline & Religiosity & 0,133 & 0,039 & 0,135 & 3,404 & 0,001 \\
\hline & Xenophobia & 0,492 & 0,026 & 0,718 & 18,584 & 0,000 \\
\hline
\end{tabular}

a. Dependent Variable: HOAX

Multiple regression analysis with the four independent variables (gender, age, education, and income) and one dependent variable namely the use of social media which is calculated in hours shows that the model used is statistically significant. The four predictor variables explained $10.5 \%$ variance of social media use $(R 2=.105, F(4,309)=9.03, p<.001)$. The calculation results show that education significantly provides predictions in a negative direction towards the use of social media $(\beta=-.29, p<.05)$, as well as income $(\beta=-.18 p<.05)$, and age $(\beta=-.034, p<.05)$. In this model, gender does not provide a statistically significant 
role $(\beta=-.26, p=.31)$. Thus, the regression equation for this model can be stated as follows; $Y$ (use of social media) $=7.28-.29$ (education) -.18 (income) -.034 (age). This means that the average use of social media will decrease by 0.29 hours for each unit of increase in education level if the other variables are constant; likewise, the average use of social media will decrease by 0.18 hours for each unit increase in the income level if the others are constant; and the average use of social media will decrease by 0.34 hours for each year of age rise.

Demographic variables are again used to estimate religiosity which is the dependent variable using multiple linear regression calculations. In this case, whether predictor variables such as gender, age, education, and income of a person have a role in determining one's level of religiosity. The calculation results show that the model used is statistically significant and the four predictor variables collectively explain $6.3 \%$ variance in religiosity ( $R 2=.063, F(4$, $309)=5.23, p<.001)$. But individually, only education showed a significant influence, giving predictions in a positive direction to religiosity $(\beta=.22, p<.001)$. The other three predictor variables did not show a significant effect on religiosity: income $(\beta=.010 p=.079)$, gender ( $\beta$ $=-.004, p=.095)$ and age $(\beta=-.005, p=.93)$. Thus, the regression equation for this model can be stated as follows; $Y$ (religiosity) $=21.17+1.27$ (education). This means that the average level of religiosity will increase by 1.27 units for each unit of increase in education level if the other factors remain.

\section{Religiosity and Xenophobia}

Multiple hierarchical regression analysis is performed to predict who is most vulnerable to xenophobia by referring to variables that have been previously analyzed, namely demographic variables (age, sex, education, and income), social media use variables, and religiosity variables. In the first step of hierarchical regression, four demographic predictors were included: education, income, gender, and age. This model is not statistically significant $F(4,309)=2.35 ; p=.055$. The inclusion of social media usage variables in step 2 shows that the model still has not shown significant results $F(5,308)=1.88 ; p=.097$. Then in the third step, by including the religiosity variable, the model is statistically significant $F(6,307)=8.70$; $p<.005$. But in the standardized final model, religiosity is the only statistically significant variable that explained $35.4 \%$ of xenophobic variants $(\beta=.354, p<0.005)$. Three other predictors did not show significant results; education $(\beta=.063, p=.25)$, income $(\beta=-.066, p$ $=.23)$, gender $(\beta=-.098, p=.068)$, age $(\beta=.034, p=.53)$, and use of social media $(\beta=.061$, $p=.276)$. The resulting regression equation is, $Y$ (xenophobia) $=12.80+51$ (religiosity). This means that xenophobia will increase by 51 points for each unit rise of religiosity. In other words, the more religious a person is, the greater the person's potential to experience xenophobia. 


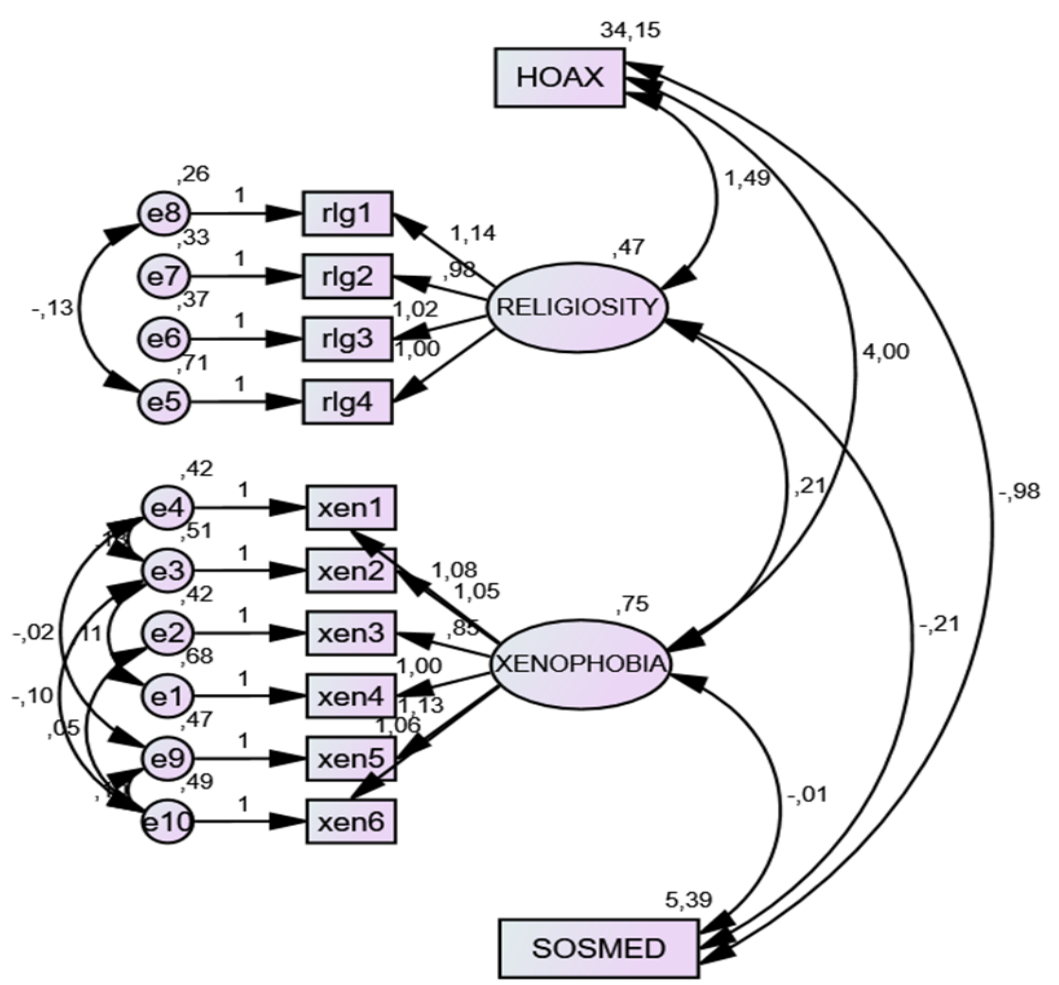

Image 2: Measurement model 


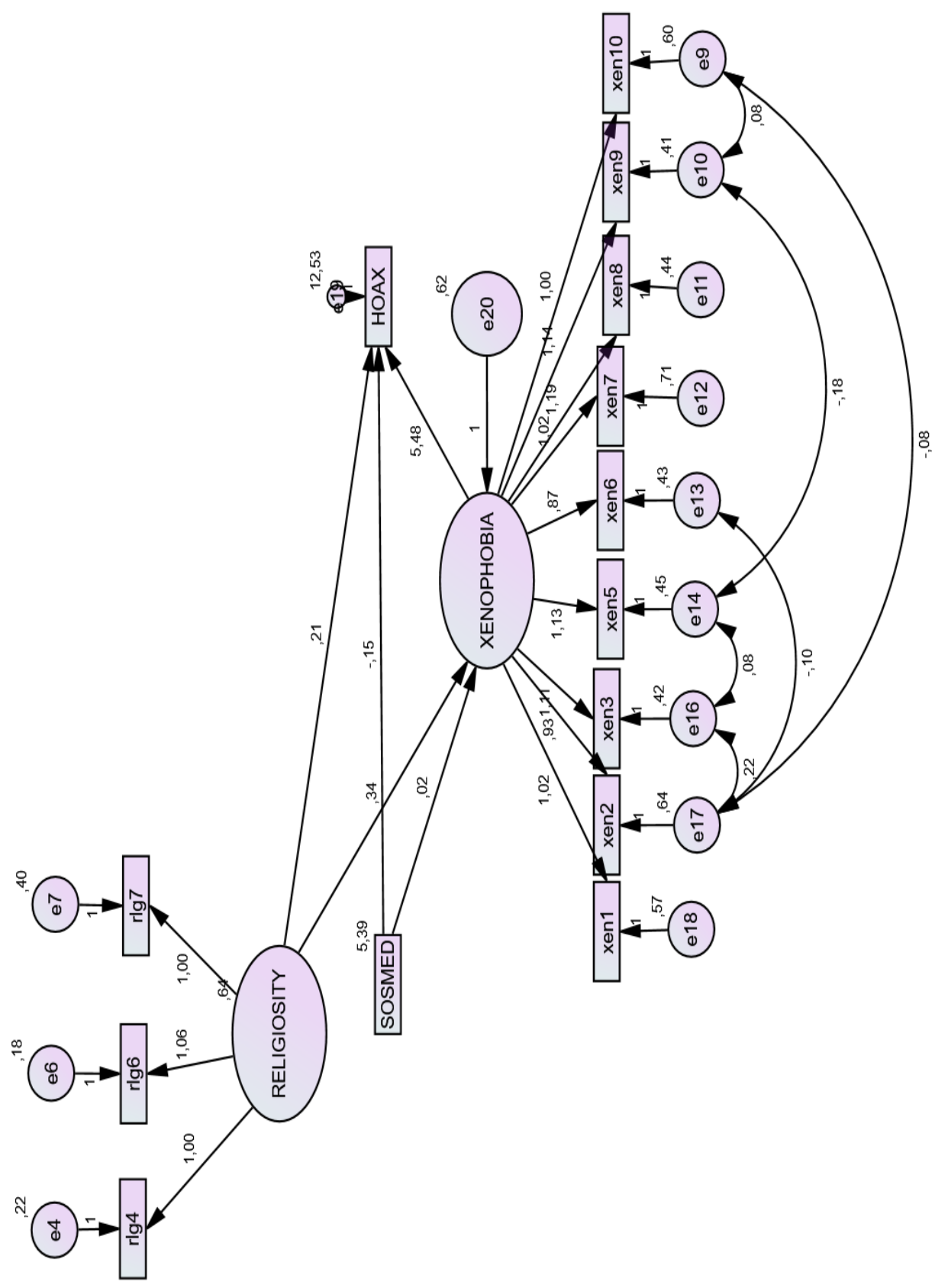

Image 3: Structural model (Final)

\section{Who believes hoaxes more?}

In the final stage, hierarchical multiple regression analysis is re-used to predict who is most vulnerable to easily believe hoaxes by referring to variables that have been previously analyzed: demographic variables (age, gender, education, and income), variables social media usage, religiosity variable, and xenophobia variable. In the first step of hierarchical regression, 
four demographic predictors were included: education, income, gender, and age. This model is not statistically significant $F(4,309)=1.88 ; p=.11$. The inclusion of social media usage variables in step 2 shows that the model still has not shown significant results $F(5,308)=$ $1.85 ; p=.103$. In the third step, by including the religiosity variable, the model is statistically significant $F(6,307)=10.40 ; p<.001$. In the final step, xenophobia is included, and the results show that the model is statistically significant $F(7,306)=68.24 ; p<.001$. In the standardized final model, only two of the seven predictor variables used were statistically significant namely religiosity $(\beta=.135, p<0.05)$ and xenophobia $(\beta=.718, p<0.001)$. While the other five predictors did not show significant results; education $(\beta=-.075, p=.047)$, income $(\beta=$ $-.017, p=.642)$, gender $(\beta=-.060, p=.100)$, age $(\beta=.026, p=.476)$, and use of social media $(\beta=-.069, p=.070)$.

The calculation results show that xenophobia gives a very large force of 71.8 percent in encouraging people to easily believe in hoax when it coupled with a religiosity that contributes $13.5 \%$. The combined strength of the two even reaches more than $85 \%$ in encouraging someone to believe in hoaxes. By using the beta coefficient value (unstandardized), the resulting regression equation can be written as follows: $Y$ (believe hoax) $=-8,034+.13$ (religiosity) +.492 (xenophobia). This means that xenophobia will increase by 51 points for every one unit of religiosity rise. In other words, the more religious a person is, the greater the potential for that person to experience xenophobia, which in turn encourages someone to more easily believe false news.

\section{Structural Model}

SEM analysis is carried out in two main steps; first, to test the measurement model and second, to test the proposed structural model. The measurement model shows how the construct is operationalized through several measured items. Confirmatory factor analysis (CFA) is used to test the reliability of the measurement model. According to Salisbury et al. (2001), CFA allows the researcher to specify the actual relationship between the items and factors as well as links between them. According to Hair et al. (2007), CFA shows construct validity, which is a measurement of the extent to which measured items can represent the latent constructs proposed in this study consisting of hoaxes (ease level of believing false news), religiosity, xenophobia and the use level of social media (Sosmed) (See Figure 2). The structural model examines the representation of the relationship between the proposed variables to tell whether the model meets the requirements to represent the conceptual relationship between the variables or not (Figure 3). 
Table 4. Model Fit Indices for Measurement Model

\begin{tabular}{lcc}
\hline Statistic & $\begin{array}{c}\text { Recommended } \\
\text { value }\end{array}$ & $\begin{array}{c}\text { Obtained } \\
\text { value }\end{array}$ \\
\hline $\begin{array}{l}\text { Chi-square } \chi 2 \\
\text { Df }\end{array}$ & $\begin{array}{c}126.2 \\
\text { X2/df (Wheaton et al, 1977; }\end{array}$ & 43 \\
$\quad$ Tabachnick dan Fidell, 2007) & & $2.00-5.00$ \\
GFI (Hooper et al., 2008; & $>0.90$ & 0.94 \\
$\quad$ Hair et al., 2007) & & \\
AGFI (Muenjohn and & $>0.80$ & 0.89 \\
$\quad$ Armstrong, 2008) & & \\
RMSEA (Hooper et al, 2008) & $<0.08$ & 0.079 \\
CFI (Watchravesringkan & $>0.80$ & 0.96 \\
$\quad$ et al., 2008) & & \\
\hline
\end{tabular}

Table 5. Model Fit Indices for Structural Model

\begin{tabular}{|c|c|c|}
\hline Statistic & $\begin{array}{l}\text { Recommended } \\
\text { value }\end{array}$ & $\begin{array}{l}\text { Obtained } \\
\text { value }\end{array}$ \\
\hline Chi-square $\chi 2$ & & 241 \\
\hline Df & & 68 \\
\hline $\begin{array}{l}\text { x2/df (Wheaton et al, 1977; } \\
\text { Tabachnick dan Fidell, 2007) }\end{array}$ & $2.00-5.00$ & 3.54 \\
\hline $\begin{array}{l}\text { GFI (Hooper et al., 2008; } \\
\text { Hair et al., 2007) }\end{array}$ & $>0.90$ & 0.91 \\
\hline $\begin{array}{l}\text { AGFI (Muenjohn and } \\
\text { Armstrong, 2008) }\end{array}$ & $>0.80$ & 0.86 \\
\hline RMSEA (Hooper et al, 2008) & $<0.08$ & 0.09 \\
\hline $\begin{array}{l}\text { CFI (Watchravesringkan } \\
\text { et al., 2008) }\end{array}$ & $>0.80$ & 0.94 \\
\hline
\end{tabular}

The reliability of the scale for the ease level of believing in hoaxes is examined by determining this model in CFA using AMOS 24. The results confirm the overall compatibility of the measurement model when used for CFA (see Table 1). Regarding the hypothesized structural model, the modification indices point to the fact that items with low factor loading need to be removed and the covariance among sets of error is also needed (say e10 and e14, and e14 and e16, etc. See Figure 3). Since these errors are on the same construct (xenophobia) so this is not the issue and after covarying the errors, this study gets the acceptable model fit. After the modification, the hypothesized structural model is supported by the overall model fit index obtained.

All fit indices are above the recommended value except for $\mathrm{c} 2 / \mathrm{df}$ values that do not meet the recommended value less than 3 (Carmines and Mclver, 1981) but are still permissible because there is no consensus on an acceptable ratio for this statistic; recommendations range from as high as 5.0 (Wheaton et al, 1977) to as low as 2.0 (Tabachnick and Fidell, 2007). Hair et al. (2007) argue that the chi-square value is sensitive to sample size 
and number of variables; Therefore, the value of $c 2 / d f$ is not taken as the only model fit indicator. All other model fit indicators are within the recommended range (see Table 2). In short, various model fit indices indicate that the proposed model matches the existing data set.

\section{Conclusions and Discussion}

Based on the results of the study it can be concluded that xenophobia and religiosity influence Muslims to easily believe in fake news. Two of the seven predictor variables tested in this study showed a statistically significant relationship with the ease with which a person believed a hoax, namely religiosity $(\beta=.135, p<0.05)$ and xenophobia $(\beta=.718, p<0.001)$ while the other five controlling predictors that include education, income, gender, age, and use of social media do not show a significant effect. The five control variables will only affect if they get influence by religiosity and xenophobia.

The calculations show that xenophobia gives an exceptionally large force of 71.8 percent in encouraging people to easily believe hoaxes while religiosity contributes $13.5 \%$. The combined strength of the two variables even reaches more than $85 \%$ to further drive Muslims to believe hoaxes. The resulting regression equation also shows that xenophobia will tend to increase with the addition of the strength of religiosity. In other words, the more religious a person is, the greater the potential for that person to experience xenophobia, which in turn encourages someone to more easily believe fake news, especially news that has a relationship with the religion they profess. At the extreme level, religiosity drives one to become fundamentalist or radical.

Analysis using structural equation modeling also supports the proposed structural model which involves four constructs namely hoaxes, religiosity, xenophobia, and social media use which shows that there is a significant influence of religiosity and xenophobia on one's ease of believing hoaxes among Muslims who use social media.

The results of this study support the view of Bronstein (2018) which shows evidence that religious fundamentalists and dogmatic individuals lack analytical thinking so they can easily believe fake news (Bronstein, 2018). The test conducted to measure the level of xenophobia in this study also supports Martin's view and is also in line with Frederick (2005) and Friedman \& Jack (2018) who through his Cognitive Reflection Test (CRT) found that dogmatic individuals are often wrong in answering intuitive questions that require analytic thinking to arrive at the right answer.

Cases related to xenophobia, namely psychological conditions of hostility or fear of outsiders, are quite common in many countries. Negative attitudes or fear towards other groups, usually minority groups, which are considered different from ones' group of origin are often displayed in public with hostility that results in physical conflict. Hostility towards minority groups is often driven by radical groups who wear various religious attributes who act as if on behalf of the majority of Islam.

The theoretical and contextual contribution of this research is to strengthen previous research which shows that xenophobia and religiosity play an important role in encouraging people to easily believe in irrational information. This study gives an important contribution because of the lack of studies on hoaxes at the moment in the midst of mushrooming of hoaxes on social media and there are no effective solutions that can be used by the governments in overcoming this problem on social media. Efforts to overcome the hoax must start from information about who is the target of the hoax. The results of this study contribute to proving that xenophobia and religiosity are two important factors that influence a person 
to easily believe false news. Xenophobia arises because of ignorance about other groups combined with beliefs in religion without rationality and critical thinking.

\section{Reference}

Allcott, H., \& Gentzkow, M. (2017). Social Media and Fake News in the 2016 Election. Journal of Economic Perspectives. Vol 31, No 2. Pages 211-236

Altemeyer, B. (2002). Dogmatic behavior among students: Testing a new measure of dogmatism. The Journal of Social Psychology, 142(6), 713-721.

Azali, K. (2017). Fake News and Increased Persecutionin Indonesia. Perspective. Yusof Ishak Institute (Iseas). Issue 2007, No 61.

https://www.iseas.edu.sg/images/pdf/ISEAS_Perspective_2017_61.pdf

Bahcekapili, H. G., \& Yilmaz, O. (2017). The relation between different types of religiosity and analytic cognitive style. Personality and Individual Differences, 117, 267-272.

Beam, M. A., Hutchens, M. J., \& Hmielowski, J. D. (2016). Clicking vs. sharing: The relationship between online news behaviors and political knowledge. Computers in Human Behavior, 59, 215-220.

Bode, L. (2016). Political news in the news feed: Learning politics from social media. Mass Communication \& Society, 19, 24-48. doi:10.1080/15205436.2015.1045149

Bronstein, M. V., Gordon, P., Adam, B. (2018). Belief in Fake News is Associated with Delusionality, Dogmatism, Religious Fundamentalism, and Reduced Analytic Thinking. Journal of Applied Research in Memory and Cognition. Https://doi.org/10.1016/j.jarmac.2018.09.005

Bronstein, M. V., \& Cannon, T. D. (2017). Bias against disconfirmatory evidence in a large nonclinical sample: Associations with schizotypy and delusional beliefs. Journal of Experimental Psychopathology, 8(1), 1-39.

Cacciatore, A. M., Sara, K., Yeo, D. A., Scheufele, M. A., Xenos, D. B., \& Elizabeth, A. C. (2018). Is Facebook Making Us Dumber? Exploring Social Media Use as a Predictor of Political Knowledge. Journalism \& Mass Communication Quarterly 00(0

Cashdan, E. (2001) Ethnocentrism and xenophobia: a cross-cultural study. Current Anthropology, 42, 760-765.

Crowther, J. (Ed.) (1995) the Oxford advanced learners dictionary of current english: international new students. (5th ed.) london: Oxford univer. Press.

Dagnall, N., Drinkwater, K., Parker, A., Denovan, A., \& Parton, M. (2015). Conspiracy theory and cognitive style: A worldview. Fron- tiers in Psychology, 6, 206.

Dewey, C. (2016). Facebook Fake-News Writer: 'I Think Donald Trump is in the White House because of Me.' Washington Post, November, 17. https://www.washingtonpost. com/news/the-intersect/wp/2016/11/17/ facebook-fake-news-writer-i-think-donaldtrump-is- in-the-white-house-because-of-me/.

DiDuca, D. (1999). Dimensions of religiosity and schizotypal traits. Unpublished doctoral dissertation. Department of Psychology, University of Essex, 1999.

DiDuca, D., \& Joseph, S. (1997). Schizotypal traits and dimensions of religiosity. British Journal of Clinical Psychology, 36, 635-638.

Duffy, A., Tandoc, E., \& Ling, R. (2019). Too good to be true, too good not to share: the social utility of fake news. Information Communication and Society. https://doi.org/10.1080/1369118X.2019.1623904

El-Menouar, Y. (2014). The Five Dimensions of Muslim Religiosity. Results of an Empirical Study. Methods, data, analyses Vol. 8(1), 2014, pp. 53-78 DOI: 10.12758/mda.2014.003 
Esses, V. M., Dovidio, J. F., Jackson, L. M., \& Armstrong, T. L. (2001) The immigration dilemma: the role of perceived group competition, ethnic prejudice, and national identity. Journal of Social Issues, 57, 389-412.

Friedman, J. P., \& Jack, A. I. (2018). What makes you so sure? Dogmatism, fundamentalism, analytic thinking, perspective taking and moral concern in the religious and nonreligious. Journal of Religion and Health, 57(1), 157-190.

Frederick, S. (2005). Cognitive reflection and decision making. The Journal of Economic Perspectives, 19(4), 25-42.

Glock, C. Y. (1962). On the Study of Religious Commitment. Religious Education, (Special Issue), 98-110. In Yasemin El-Menouar (2014). The Five Dimensions of Muslim Religiosity. Results of an Empirical Study. Methods, data, analyses Vol. 8(1), 2014, pp. 53-78 DOI: 10.12758/mda.2014.003

Gottfried, J., \& Elisa S (2016). News Use across Social Media Platforms 2016. Pew Research Center, May 26. http://www. journalism.org/2016/05/26/news-use-across- socialmedia-platforms-2016.

Ho, S. S., Yang, X., Thanwarani, A., \& Chan, J. M. (2016). Examining public acquisition of science knowledge from social media in Singapore: An extension of the cognitive media- tion model. Asian Journal of Communication, 27, 193-212. doi:10.1080/01292986.2016.1 240819.

Huber, S. (2003). Zentralität und Inhalt: Ein neues multidimensionales Messmodell der Religiosität. Opladen: Leske and Budrich.

Huber, S. (2004). Zentralität und Inhalt. Eine Synthese der Messmodelle von Allport und Glock\|. In Religiosität: Messverfahren und Studien zu Gesundheit und Lebensbewältigung. Neue Beiträge zur Religionspsychologie, edited by Christian Zwingmann, and Helfried Moosbrugger. Münster: Waxmann, 79-105.

Huber, S. (2007). Are religious beliefs relevant in daily life?\| In Religion Inside and Outside Traditional Institutions, edited by Heinz Streib. Lieden: Brill Academic Publishers, 211230.

Huber, S. (2008). Kerndimensionen, Zentralität und Inhalt. Ein interdisziplinäres Modell der Religiosität.|l Journal für Psychologie 16 (2008): Article 05. www.journal-fuerpsychologie.de/jfp-3-2008-05.html.

Huber, S. (2009). Religion Monitor 2008: Structuring principles, operational constructs, interpretive strategies. || In What the World Believes: Analysis and Commentary on the Religion Monitor 2008, edited by Bertelsmann-Stiftung. Gütersloh: Verlag BertelsmannStiftung, 17-51.

Huber, S., \& Huber, W. O. (2012). The Centrality of Religiosity Scale (CRS). Religions 2012, 3, 710-724; doi:10.3390/rel3030710

Hui, J. Y. (2018). Fake News as Shared Challenge: Mutual Learning through Case Study of Indonesia. Centre of Excellence for National Security (CENS). Https://www.parliament.gov.sg/docs/default-source/sconlinefalsehoods/writtenrepresentation-82.pdf

Husted, B. (2018). What is the difference between Fake News and Hoax? https://www.quora.com/What-is-the-difference-between-Fake-News-and-Hoax

Jaipragas, B. (2016). "How Indonesia's anti-Chinese fake news problem spun out of control," South China Morning Post, December 22, 2016, http://www.scmp.com/weekasia/politics/article/2056627/how-indonesias-anti-chinese-fake-news-problem-spunout-control 
Joseph, S., \& Diduca, D. (2007). The dimensions of religiosity scale: 20 -item self-report measure of religious preoccupation, guidance, conviction, and emotional involvement. Mental health, religion \& culture 10(6): 603-608

Karlsson, S. (2010). Xenophobia in Europe Testing economic interests and national identity. Lunds universitet. Statsvetenskapliga institutionen.

Http://lup.lub.lu.se/luur/download?func=downloadFile\&recordOId=1524889\&fileOId= 1525070

Lazer, D. M., Baum, M. A., Benkler, Y., Berinsky, A. J., Greenhill, K. M., Menczer \& Schudson, M. (2018). The science of fake news. Science, 359(6380), 1094-1096.

Lee, E.-J., \& Oh, S. Y. (2013). Seek and you shall find? How need for orientation moderates knowledge gain from Twitter use. Journal of Communication, 63, 745-765. doi:10.1111/ jcom.12041.

Levin, J. S., Chatters, L. M., \& Taylor, R. J. (1995). Religious effects on health status and life satisfaction among Black Americans. Journal of Gerontology:Social Sciences 50B:S154S163.

Mahudin, N. D. M., Noraini, M. N., Mariam, A. D., \& Nazariah, S. J (2016). Religiosity among Muslims: A Scale Development and Validation Study. Makara Hubs-Asia, 20(2): 109-120 DOI: $10.7454 /$ mssh.v20i2.3492

Martin, N. (2008). Examination of the belief bias effect across two domains of reasoning (Master's thesis). University of Waterloo.

Parkinson, H. J. (2016). Click and Elect: How Fake News Helped Donald Trump Win a Real Election. Guardian, November 14.

Pearce, L. D., Hayward, G. M., \& Pearlman, J. A. (2017). Measuring Five Dimensions of Religiosity across Adolescence. Review of Religious Research 59: 367. https://doi.org/10.1007/s13644-017-0291-8

Pechey, R., \& Halligan, P. (2011). The prevalence of delusion-like beliefs relative to sociocultural beliefs in the general population. Psychopathology, 44(2), 106-115.

Pennycook, G., Cheyne, J. A., Barr, N., Koehler, D. J., \& Fugelsang, J. A. (2014). Cognitive style and religiosity: The role of conflict detection. Memory \& Cognition, 42(1), 1-10.

Pennycook, G., Ross, R. M., Koehler, D. J., \& Fugelsang, J. A. (2016). Atheists and agnostics are more reflective than religious believers: Four empirical studies and a meta-analysis. Plos One, 11(4), e0153039.

Rampersad, G., \& Althiyabi, T. (2020). Fake news: Acceptance by demographics and culture on social media. Journal of Information Technology \& Politics, 17(1), 1-11. https://doi.org/10.1080/19331681.2019.1686676

Reynolds, V., \& Vine, I. (1987) The sociobiology of ethnocentrism: Evolutionary dimensions of xenophobia, discrimination, racism, and nationalism. London: Croom helm.

Rössler, W., Ajdacic-Gross, V., Haker, H., Rodgers, S., Müller, M., \& Hengartner, M. P. (2015). Subclinical psychosis syndromes in the general population: Results from a large-scale epidemiological survey among residents of the canton of Zurich, Switzerland. Epidemiology and Psychiatric Sciences, 24(1), 69-77.

Shenhav, A., Rand, D. G., \& Greene, J. D. (2012). Divine intuition: Cognitive style influences belief in God. Journal of Experimental Psychology: General, 141(3), 423-428.

Silverman, C. (2016). This Analysis Shows how Fake Election News Stories Outperformed Real News on Facebook. BuzzFeed News, November 16.

Silverman, C., \& Jeremy, S-V., (2016). Most Americans Who See Fake News Believe It, New Survey Says. BuzzFeed News, December 6. 
Soeriaatmadja, W. (2017). Indonesian police probe alleged fake news factory's protest links. The Straits Times, August 26, 2017, http://www.straitstimes.com/asia/seasia/indonesian-police-probe-alleged-fake-news-factorys- protest-links.

Subramanian. (2017). Inside the Mace- donian Fake-News Complex. Wired, February 15.

Taliwang, M. H. (2014). Musuh Bangsa Kita: Asing, Aseng dan Asong. Http://iepsh.org/asingaseng-asong/

Torto, F. (2018). What is the difference between Fake News and Hoax? https://www.quora.com/What-is-the-difference-between-Fake-News-and-Hoax

Townsend, T. (2016). Meet the Romanian Trump Fan behind a Major Fake News Site. Inc. http://www. inc.com/tess-townsend/ending-fed- trump-facebook.html.

Van Os, J., H., M., Bijl, R. V., \& Ravelli, A. (2000). Strauss (1969) revisited: A psychosis continuum in the general population? Schizophrenia Research, 45(1), 11-20.

Wach, J. (1944). Sociology of Religion. Chicago: University of Chicago Press. In Pearce, L.D., Hayward, G.M. \& Pearlman, J.A (2017). Measuring Five Dimensions of Religiosity across Adolescence. Review of Religious Research 59: 367. https://doi.org/10.1007/s13644-017-0291-8

Yakushko, O. (2009). Xenophobia: understanding the roots and consequences of nega- tive attitudes toward immigrants. the Counseling Psychologist, 37, 36-66.

Yoo, S. W., Gil de \& Zúñiga, H. (2014). Connecting blog, Twitter and Facebook use with gaps in knowledge and participation. Communication \& Society, 27(4), 33-48.

Zawadzki, J. A., Woodward, T. S., Sokolowski, H. M., Boon, H. S., Wong, A. H. C., \& Menon, M. (2012). Cognitive factors associ- ated with subclinical delusional ideation in the general population. Psychiatry Research, 197(3), 345-349. 